\title{
THE SYSTEM OF SOCIAL SERVICES IN BULGARIA AND THE PROCESS OF DEINSTITUTIONALISATION OF CHILDREN
}

\author{
Venelin Terziev \\ Academician of the Russian Academy of Natural History, Moscow, Russia, Prof. D.Sc. (Ec.), D.Sc. \\ (National Security), D.Sc. (Social Activities), Ph.D., National Military University, Veliko Tarnovo, \\ Bulgaria; University of Rousse, Rousse, Bulgaria, terziev@skmat.com
}

\begin{abstract}
Development of social services in Bulgaria is predetermined by the policies of last decades of the last century and is characterized by a number of features arising from the difficult transition to a market economy and modern challenges of dynamic social and economic environment. Social services are activities targeted at supporting assisted persons to conduct a complete way of life and full inclusion in society. Social services are aimed mainly at social integration of people, giving them the opportunity to lead an independent life and not to be dependent on the service or the institution. Development of social services in community is the key to effective social inclusion, poverty alleviation and participation in society of all vulnerable groups. In recent years, policy in the sphere of social services in Bulgaria is directed to development of services in community and home to replace the institutional model of care. Planning and implementation of national policy of reforms in child care is directly related to children at risk and better recognition of their problems and needs. Purposeful activities are carried out and programs are being implemented to achieve one of the main objectives of this policy - deinstitutionalization of children. Based on European practices and models activities and methods of child care are successfully realized. Presented study on the development of social services for children, with a special emphasis on deinstitutionalization, makes analyses of the system of social services for children as set in main strategic documents and statistical data. The aim is to identify key processes, trends and issues and to make recommendations for policy improvements. Main results emphasize that in order to achieve the desired effects new approaches and measures are needed in application of running strategies. Main recommendations are defined for implementation of social policies for children and a conceptual framework of child care is proposed. It is important and necessary to develop a policy that will not only offer appropriate care for children at risk in the short term, but will also to prevent possible problems in the future.
\end{abstract}

Keywords: Social services, institutional care, deinstitutionalization

\section{INTRODUCTION}

In many countries, institutionalization is seen as a countermeasure of poverty and of the partial measures to support the family. This leads to unnecessary placements, often when biological parents are alive and able to care for their children if they are properly supported. Therefore, policies should focus on the prevention of child abandonment and on greater placement of children without parental care by caregivers. This should be 
accompanied by national monitoring systems and standardized indicators. However, there is little willingness to initiate political reform, either because of weak evidence base, inertia of the existing system of allocating resources, lack of a clear strategic planning and implementation, and also the often expressed fear of increased costs.

The cost of institutional care looks different than the cost of foster care and placement with friends and relatives. Resident care in the community is more expensive than foster and institutional; however, as startup costs are amortized once, they can be smaller than the current expenditure of large institutions, while offering better quality of care. In many cases, it is proposed to be redirected resources to community services by changing the financial flows to support families at risk.

Institutional care is leading in most Eastern European countries. There are differences in the availability of foster care and residential care in the community as an alternative to institutional care; some countries did not have foster care, while others use mainly these approaches to children at risk.

All cases demonstrate the absolute advantage of the results of community-based services over institutional. The advantage is evident in all aspects (physical, mental, social, educational, etc.) and cannot be challenged even by the best institutional services. Indeed, institutional care is often described as self-serving and thus difficult to support the principle of protecting the best interests of the child.

\section{SYSTEM OF SOCIAL SERVICES FOR CHILDREN}

The social services in Bulgaria are divided into two types depending on the environment they are provided social services provided in community and social services in specialized institutions.

Social services in the community are: personal assistant, social assistant, home helper, home care; Day Care Center, Center for Social Rehabilitation and Integration, Center for temporary placement, Foster Care, Crisis Center, Center for family-type placement, group homes, soup kitchens.

Specialized institutions are: homes for children or young people with disabilities, homes for adults with disabilities, social educational professional establishments, retirement homes, shelters, homes for temporary placement.

In Bulgaria there are the following types of child care:

Institutional Care (132 institutions with 6254 children according to data for the end of 2010): institutions are part of the socialist legacy dominated by the understanding that the state is able to care for children better than their families. The institutional system is characterized by long-established structures and powerful momentum that understands "reform" and "restructuring" as repairing existing infrastructure without significant change in the way of childcare.

Foster care and placement with friends and relatives (12 664 children since the beginning of the reform by the end of 2010): foster care and placement with relatives is understood as a child in the home of a certified by the state party (professional or voluntary foster care) or by members of the biological family other than parents (placement with friends and relatives). The placement with friends and relatives is well developed for the period 2000-2010 are housed 12105 children. Foster care is also evolving, as it is expected to become a major element, especially in the process of reintegration of institutionalized children in their biological families. The total number of children in foster care since the beginning of the reform by the end of 2010 is 559 of which 221 were accommodated in 2010.

Residential care in the community (72 centers with a capacity of 831 children up to mid - 2011): residential care in the community can be seen as an intermediate body between the institutional and foster care and placement with relatives. In residential care children live in "family-like" environment, even in larger, spatially separated communities with high staff-child ratio. In Bulgaria the longest working provider of social services in the community residential care is "SOS Kinderdorf". Yet recently a number of new social services of residential type began operating. Significant efforts have been made by all stakeholders to ensure efficient and effective process of deinstitutionalization. The resources of the Bulgarian government and European funds are used to support this process.

In 2008 Bulgaria adopted a National Strategy for Children 2008-2018, and in 2010 adopted the National Strategy "Vision for deinstitutionalization of children in Bulgaria" according to which deinstitutionalization is a process of replacing institutional care for children care in the community in a family or family-like environment. It is a process of prevention of placement of children in institutions by creating new opportunities for children and families to receive support in the community. One of the main challenges in the process is diverting resources from the old system of institutional care to community - based services on the 
principle "money follows the child", i.e. resources are directed to services to meet the specific needs of children and families.

\section{CHALLENGES TO THE SYSTEM OF SOCIAL SERVICES FOR CHILDREN}

Deinstitutionalization is the basis of the National Strategy for Children and National Strategy "Vision for deinstitutionalization of children in Bulgaria" and is the process of replacing institutional care for children with care in a family or family-like environment in the community, not limited to the children leaving institutions. This is the process of preventing the placement of children in institutions, creating new opportunities for children and families to receive support in the community.

One purpose of this type of services is aimed at teaching children to build skills for independent living and promoting social inclusion. Another goal is specialized work with children who are returning to the family environment; prevention of abandonment and counseling of parents. Over the years stability has been ensured, all social services are financed by the state budget as specialized ones.

Institutions for children are part of the legacy left by the totalitarian state in which the approved policy is based on the idea that the state is able to care better for the upbringing of children than their families. This policy, continued for more than 40 years, has leaved lasting traces on public attitudes and mentality of people in the country. The institutionalization of child care in Bulgaria continues to be an unresolved issue that cannot be explained only with the totalitarian past. The lack of a clear political will to close the homes lead to their "reform" and "restructuring" that are often perceived as a repair of the buildings and did not lead to a significant change in the way of care and children's lives.

Economic, political and social changes that accompany the transition give rise to new challenges and exacerbate existing problems. Some of the key factors that influence the institutionalization are:

- Insufficient number of services for children and families that should meet complex needs and uneven distribution throughout the country;

- Lack of financial resources, which often results in the exclusion of families and placement of children in institutions;

- Lack of a developed system of alternatives to community-based institutional care;

- A prevailing medical model to a child's disability, according to which the institution offers the best care for children;

- Lack of inclusive social and architectural environment;

- Changed patterns of family behavior that lead to an increase in illegitimate births and parents who provide care for children on their own.

Placement of children in institutions violates their rights guaranteed by international conventions to which Bulgaria is a party (UN Convention on the Rights of the Child, Convention on the Rights of People with Disabilities) and leads to establishment of discriminatory patterns in education and access to quality care and services.

Regardless of the input resources, the lives of institutionalized children of boarding type are not becoming better and services of higher quality. The institutional life does not imply the existence of a trust relationship with one constant adult, individual care, attention and personal space for the child. It cannot satisfy the basic needs of children and adversely affects their development and behavior. This in turn leads to further economic and social cost to society.

In this regard, implementation of an effective policy for deinstitutionalization requires a change in the philosophy of child care with an emphasis on:

- Prevention of risks;

- Early Intervention;

- Support to the families and assurance of family or family-like environment.

These actions are based on a policy in the best interests of the child aimed at supporting families, and create the best conditions for development of children and realize their full potential. This policy is also based on respect for child rights norms, standards and principles of universality, indivisibility and non-discrimination, while characterized by a high sensitivity, flexibility and preparedness to meet the challenges. 


\section{MAIN FEATURES OF THE POLICY OF DEINSTITUTIONALIZATION OF CHILDREN}

Deinstitutionalization is the process of replacing institutional care for children with care in a family or familylike environment in the community, not limited to the children leaving institutions. This is the process of preventing the placement of children in institutions, creating new opportunities for children and families receive support in the community and takes place on many levels:

- Working with families and professionals from social and close to it areas on prevention of abandonment and institutionalization of children with a view to limiting and gradually cease placing of children in institutions and to support the reintegration of children in their native families;

- Reform and work in the social welfare system for the implementation of programs for social support and protection to support the home and extended family for the prevention of abandonment and raising children in a family environment;

- Opening alternative forms of services and care to create an opportunity for the children to get out of institutions or prevent their placement;

- Promote the development of adoption and foster care with a focus on development of services for children of 0 - 3 years;

- Engaging the public in support of children leaving institutions for their social inclusion;

- Putting children and families at the center of the work of all those working with children.

The basic principles are related to:

- Actions to protect the best interests of the child according to the UN Convention on the Rights of the Child is the guiding principle that the interests of the child should be placed above the interests of all others, including parents, potential adoptive parents, foster parents or staff of the institution.

- The family is the best environment for child development - all working in the field of deinstitutionalization should have a common understanding about the negative impact that institutional care has on children and how is important a child to grow in a family environment.

- The social inclusion of children is of paramount importance - it must be achieved by providing opportunities for all children to participate in all aspects of community life, including attending local kindergartens and schools and use local health, transport and other public services.

The approaches in the process of deinstitutionalization should be:

- Each child should be a subject of a needs assessment that includes an evaluation of parental capacity and the opportunity the child to be grown up in his/her family;

- No child should be get out of an institution without a plan of action and care co-developed with the people who now and in the future will take care of him/her, and with the participation of the birth family when possible;

- Maintaining contact and emotional connection between the biological family and the child, whenever possible, should be a key element of providing constant care for each child, whether or not there is an opportunity for future reintegration;

- For all children from institutions under closure placement should be provided in a family or family-like environment, no child should be omitted;

- Institutions are not closed by moving children from one institution to another;

- Providing an advantage to placement in a family environment - in service demand alternative to stay in an institution, first to make every effort to reintegrate the child into his/her family when it is appropriate and does not endanger the child's life. When this is not possible, to seek for an opportunity for long-term solution in the best interest of the child - first seek for placement in a family of friends or relatives, then in foster or adoptive parents;

- Children are placed in residential care services for small children only when it is not possible family placement, the demand for family form of care in the system of protection does not stop with the placement;

- The search for a permanent solution for the child is a key part of the action plan to minimize his/her transfer from one form of care to another; 
- Children should be included as much as possible in making decisions about the form of care that will be selected;

- Siblings must be collected and kept together, unless it is appropriate and possible;

- After getting out of children from institutions, their capacity must be reduced to final closure;

- Institutions for children with disabilities will be closed with a priority in parallel with homes for medical and social care of $0-3$ years as the stay of children in institutions of this kind and at this age is the most detrimental to their development;

- Active involvement of the staff of the institutions in the process of deinstitutionalization, development and implementation of programs for retraining and directing staff to alternative social services in order to use the existing capacity and human resources.

- The main goal is ensuring children's right to family environment and access to quality care and services according to their individual needs.

Specific targets are related to:

- Statutory regulations, funding and staffing of a wide range of services for children and families in the community, based on best practices and attracting innovative approaches;

- Increasing the capacity in the system of child protection by clearly defined and efficient allocation of powers and responsibilities of child protection, service providers and the provision of adequate professional capacity for the effective operation of the system;

- Closure of 137 institutions for children within 15 years;

- Preventing placement and raising children of 0 to 3 years in residential care of any type after the reform.

Achieving these goals requires an integrated comprehensive policy on children and families, and changes in the following sectorial policies:

- Adopting a broader concept of welfare of all children and guaranteeing their rights;

- Services to support parents to fulfill their responsibilities to children, not the state to assume these responsibilities, and improving the quality and effectiveness of alternative forms of care and services;

- Modern approach to health care which supports mothers before, during and after the birth of their children, and does not allows ill children and children with special needs to be separated from their parents for long periods of time;

- An educational system that has the capacity and resources to support different needs of all children;

- System for child protection which is clearly differentiated from the social assistance system;

- Favorable and appropriate for child justice system where any child who appears in court - whether as a victim of crime or accused of involvement in crime - should be treated first and foremost as a child;

- Introducing a new approach to financing of services for children in which resources are directed to services to meet the specific needs of children and families and their effectiveness, not the buildings where they are provided. The financial resources intended to meet the needs of children to follow users who have successfully got out of institutions, accordingly reducing capacity and funding of the institution (Terziev, Georgiev, 2018a-d; Terziev, Banabakova, Georgiev, 2018e-o; Dimitrova, Georgiev, 2017a-b).

\section{CONCEPTUAL FRAMEWORK OF CHILD CARE}

Looking at the whole process and the differentiation of types of care the following generalizations and conclusions are made in comparative analyses on the costs and benefits of the child care system in Bulgaria.

In terms of investments:

Resident care in the community is evaluated based on leaving SOS children's villages. However, it is expected that most of the results to be applicable to all relevant services. They have the highest, but clear and understandable operating expenses on the ratio "placement of a child for per year".

Foster care is the cheapest in terms of the ratio " placement of a child for per year" when into account only the cost of the state budget is taken and it is comparable to the cost of institutional care that takes into 
account the total cost. Placement with friends and relatives is currently the most promising in terms of cost. However, given the decentralized approach, quality assurance and standards of service are significant.

Institutional care demonstrates a relatively low cost in relation to the ratio " placement of a child for per year". Although the cost structure of state institutions does not reflect the overall costs, it can be argued that institutional care for a child can be significantly more expensive, when economies of size are not taken into account.

With regard to the modernization of services, resident care in the community and foster care are equally good, while institutional care is lagging behind.

In terms of results:

The leaving residential care in the community has relatively high educational achievement - mostly secondary specialized education. They usually find jobs after graduation and do not continue with further education. They have an independent lifestyle, skillfully cope with everyday tasks, and refrain from abuse of drugs and alcohol or risky behavior. They have relatively the most stable working conditions and communicate in an expanded social network. They see themselves at the level of their peers and are generally satisfied with their lives.

Leaving foster care / placement with friends and relatives behave in a similar way to leaving residential care in the community. However, they reach higher educational level and continue their education after school, adhere to the educational model of the majority of the population and follow the line with the accepted careers. This may be due to the higher level of education, the larger number of social contacts, availability of employees as models in their surroundings and relative ease of use of channels for employment. In some cases, care leavers demonstrate the immature behavior of leaving residential care in the community and institutional care.

The leaving institutional care have reached the lowest educational level and work in unstable conditions. As a result, generally they earn less than the other two groups and rely on social assistance. They have less developed social networks and often socialize primarily with other leaving the institutional care. Their lifestyle is unhealthy, on the other hand, they express the opinion that they are in better health, which is likely due to the need to adapt to worse health services ("survival"), low susceptibility to health problems and difficulties in accessing health services. There is a trend older leaving institutional care to demonstrate better adaptation to independent life in terms of housing, work, income, mature behavior, compared with younger ones. At the same time, they represent less on issues related to mental health and smoking. Ultimately, the price for the aim of successful integration in life is the higher health risk. This finding needs further study in terms of estimated costs of mental and physical problems.

For the quality of the "results" of the leaving residential care in the community and foster care are the higher benefits for society in terms of income, employment, health and criminal record.

In terms of the ratio of costs and benefits foster care / placement with friends and relatives is undisputed. Resident care in the community gives such good results, although it is hampered by the high costs per child.

Institutional care provides low-quality results with low cost per child and in some cases out performers only the residential care in the community (Terziev, Banabakova, Arabska, 2018p; Terziev, Arabska,

Banabakova, Kovalyov, 2018q; Terziev, Arabska, Banabakova, Ignatova, Kovalyov, 2018r; Terziev, Arabska, Banabakova, 2018s; Terziev, 2016a; Terziev, 2017c; Terziev, Radev, Arabska, Dimitrovski, 2017d; Terziev, 2017e).

Based on the analyzes proposals can be defined (Table 1) and a common conceptual framework for child care can be presented (Table 2).

Table 1. Proposals based on the analyzes.

\begin{tabular}{|l|l|l|}
\hline Issue & Time dimension & Addressees \\
\hline Research & State institutions \\
\hline $\begin{array}{l}\text { Actively disseminate the results } \\
\text { of the research to inform public } \\
\text { opinion about the benefits and }\end{array}$ & Short to medium term & \\
\hline
\end{tabular}




\begin{tabular}{|c|c|c|}
\hline $\begin{array}{l}\text { costs of each system for the } \\
\text { care of children who can be } \\
\text { helpful in the process of political } \\
\text { decision-making. }\end{array}$ & & \\
\hline $\begin{array}{l}\text { Introduction of the new } \\
\text { paradigm in the analysis of the } \\
\text { needs of children and overall } \\
\text { development in their response. }\end{array}$ & Short to medium term & $\begin{array}{l}\text { Service providers, academic } \\
\text { and research institutions. }\end{array}$ \\
\hline $\begin{array}{l}\text { Establishing a system for long- } \\
\text { term collection and analysis of } \\
\text { data on progress in the } \\
\text { development of children in the } \\
\text { process of care and long-term } \\
\text { effects of different types of care } \\
\text { for children / youth in their lives } \\
\text { as adults. }\end{array}$ & Medium term & $\begin{array}{l}\text { State institutions, } \\
\text { providers, academic } \\
\text { research institutions. }\end{array}$ \\
\hline $\begin{array}{l}\text { Introducing the methodology of } \\
\text { the analysis of costs and } \\
\text { benefits / opportunity for ex- } \\
\text { ante and ex-post evaluation of } \\
\text { the current and the reformed } \\
\text { system of care for children. }\end{array}$ & Medium to long term & $\begin{array}{l}\text { State institutions, } \\
\text { providers, academic } \\
\text { research institutions. }\end{array}$ \\
\hline \multicolumn{3}{|l|}{ Policy } \\
\hline $\begin{array}{l}\text { Develop a policy promoting } \\
\text { priority support to the biological } \\
\text { family over foster family and } \\
\text { residential care to community. }\end{array}$ & Short to medium term & State institutions \\
\hline $\begin{array}{l}\text { Conceptualization of a wide } \\
\text { range of services related to } \\
\text { family support and substitute } \\
\text { care. }\end{array}$ & Short to medium term & $\begin{array}{l}\text { State institutions, service } \\
\text { providers }\end{array}$ \\
\hline $\begin{array}{l}\text { Raising awareness and } \\
\text { improving the participation of } \\
\text { the leaving, care recipients and } \\
\text { care providers in the process of } \\
\text { political decision-making. }\end{array}$ & Medium to long term & $\begin{array}{l}\text { National and local institutions, } \\
\text { research NGO in community }\end{array}$ \\
\hline $\begin{array}{l}\text { Increasing funding for foster } \\
\text { care / placement with relatives } \\
\text { and resident care in the } \\
\text { community. }\end{array}$ & Permanently & State institutions \\
\hline \multicolumn{3}{|l|}{ Services } \\
\hline $\begin{array}{l}\text { Definition of quality standards, } \\
\text { funding and accountability, } \\
\text { taking into account the } \\
\text { fulfillment of the needs of } \\
\text { children. }\end{array}$ & Short term & $\begin{array}{l}\text { State institutions, service } \\
\text { providers }\end{array}$ \\
\hline $\begin{array}{l}\text { Definition of the specifications } \\
\text { for "smart placement", ie }\end{array}$ & Short to medium term & State institutions, service \\
\hline
\end{tabular}




\begin{tabular}{|c|c|c|}
\hline $\begin{array}{l}\text { appropriate placement of } \\
\text { children in accordance with } \\
\text { their needs in the logic of } \\
\text { "priority support to the biological } \\
\text { family, foster family and } \\
\text { residential care in the } \\
\text { community". }\end{array}$ & & providers \\
\hline $\begin{array}{l}\text { Developing a monitoring system } \\
\text { to monitor the path of every } \\
\text { child in an appropriate care } \\
\text { system. }\end{array}$ & Short to medium term & Service providers \\
\hline $\begin{array}{l}\text { Improving the qualifications and } \\
\text { training of carers with the aim of } \\
\text { adopting new working methods. }\end{array}$ & Medium term & Service providers \\
\hline
\end{tabular}

Table 2. Common conceptual framework of child care.

\begin{tabular}{|c|c|c|c|c|}
\hline 1. NEEDS & 2. SERVICES & 3. INPUTS & 4. RESULTS & 5. IMPACT \\
\hline $\begin{array}{l}\text { 1.1. Physical } \\
\text { needs }\end{array}$ & $\begin{array}{l}\text { 2.1. "Physical } \\
\text { services" }\end{array}$ & \multirow{12}{*}{$\begin{array}{l}\text { 3.1. Financial } \\
\text { resources; } \\
\text { 3.2. Material } \\
\text { resources; } \\
\text { 3.3. Human } \\
\text { resources; } \\
\text { 3.4. Additional } \\
\text { resources } \\
\text { (donations); } \\
\text { 3.5. Hidden } \\
\text { costs } \\
\text { (investments } \\
\text { related to the } \\
\text { "social" } \\
\text { services). }\end{array}$} & \multirow{12}{*}{$\begin{array}{l}\text { 4.1. Results } \\
\text { related to } \\
\text { personal } \\
\text { sustainability; } \\
\text { 4.2. Results } \\
\text { related to } \\
\text { sociability; } \\
\text { 4.3. Results of } \\
\text { the personality / } \\
\text { maturity; } \\
\text { 4.4. Horizontal } \\
\text { results. Life skills. }\end{array}$} & \multirow{12}{*}{$\begin{array}{l}\text { 5.1. "Direct" } \\
\text { benefits: } \\
\text { 5.1.1. Sources of } \\
\text { revenues; } \\
\text { 5.1.2. History of } \\
\text { employment; } \\
\text { 5.1.3. Economic } \\
\text { activity; } \\
\text { 5.1.4. Criminal } \\
\text { offenses; } \\
\text { 5.1.5. State } \\
\text { transfers; } \\
\text { 5.1.6. Tax } \\
\text { contribution; } 5.1 .7 \text {. } \\
\text { Health status; } \\
\text { 5.2. Additional } \\
\text { impacts } \\
\text { (complementary } \\
\text { direct benefits): } \\
\text { 5.2.1. Educational } \\
\text { attainment; } 5.2 .2 \text {. } \\
\text { Risky behavior; } \\
\text { 5.2.3. Family status; } \\
\text { 5.3. Impacts in the } \\
\text { context of: } \\
\text { 5.3.1. Housing } \\
\text { conditions; } 5.3 .2 \text {. } \\
\text { Social activities in } \\
\text { leisure time; } 5.3 .3 \\
\text { Quality of life. }\end{array}$} \\
\hline \multirow{3}{*}{$\begin{array}{l}\text { Food, shelter, } \\
\text { sleep and rest, } \\
\text { health, sexual } \\
\text { education, } \\
\text { personal space. }\end{array}$} & \multirow{3}{*}{$\begin{array}{l}\text { Food provision, } \\
\text { hygiene, shelter, } \\
\text { medical care, } \\
\text { dental care, } \\
\text { providing } \\
\text { autonomy. }\end{array}$} & & & \\
\hline & & & & \\
\hline & & & & \\
\hline $\begin{array}{l}\text { 1.2. Emotional } \\
\text { needs }\end{array}$ & $\begin{array}{l}\text { 2.2. "Emotional" } \\
\text { services }\end{array}$ & & & \\
\hline Pleasure, & Sport, games, & & & \\
\hline $\begin{array}{l}\text { emotional } \\
\text { development, } \\
\text { personal }\end{array}$ & $\begin{array}{l}\text { relationship with } \\
\text { the most important } \\
\text { person, providing }\end{array}$ & & & \\
\hline $\begin{array}{l}\text { belongings, } \\
\text { personal success, } \\
\text { to love and to be } \\
\text { loved. }\end{array}$ & $\begin{array}{l}\text { personal } \\
\text { belongings, } \\
\text { personal } \\
\text { communication }\end{array}$ & & & \\
\hline $\begin{array}{l}\text { 1.3. Cognitive } \\
\text { needs }\end{array}$ & $\begin{array}{l}\text { 2.3. "Cognitive" } \\
\text { services }\end{array}$ & & & \\
\hline $\begin{array}{l}\text { Cognitive } \\
\text { development, } \\
\text { confidence, a }\end{array}$ & $\begin{array}{l}\text { Training, access to } \\
\text { various forms of } \\
\text { experience, }\end{array}$ & & & \\
\hline $\begin{array}{l}\text { stimulation, } \\
\text { learning, } \\
\text { independence, to } \\
\text { be important to } \\
\text { someone. }\end{array}$ & $\begin{array}{l}\text { development, } \\
\text { access to books, } \\
\text { internet, movie. }\end{array}$ & & & \\
\hline 1.4. Social needs & 2.4. "Social" & & & \\
\hline
\end{tabular}




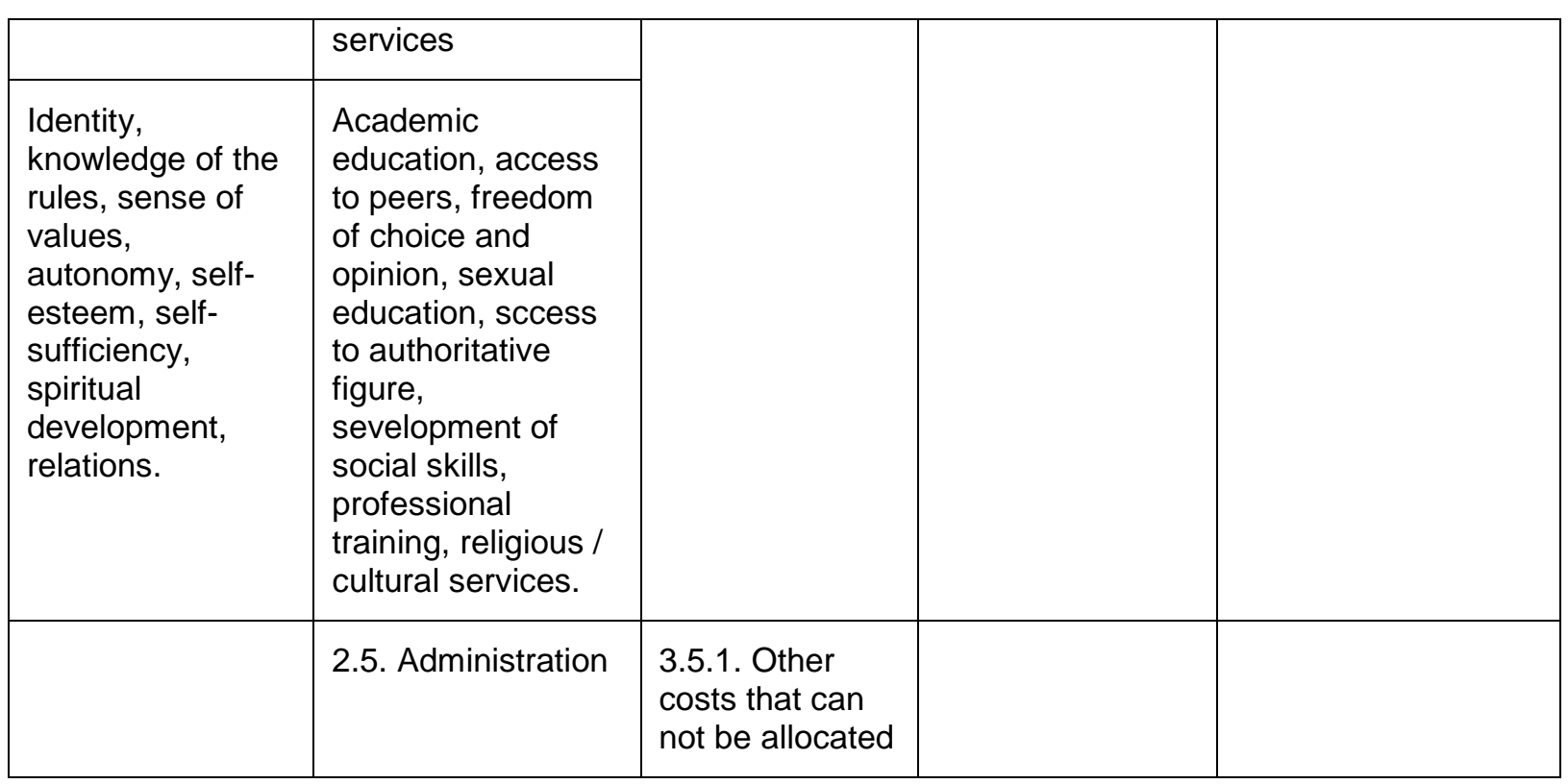

\section{CONCLUSION}

Construction and development of a qualitatively new system of providing social services in Bulgaria is a process that can be completed with the adoption of a set of strategies, programs and projects. The normative definition of this process does not lead to automatically getting better and sharper results. The reasons for the difficulty of this process are many and of different nature, but in any case they are related to previously existing activities and services, the capacity of the Bulgarian social services, and - not least - of public attitudes. Public opinion, as a corrective to social interests, accepts always uniquely specific actions of social public services, gives high public significance of certain phenomena and specific cases. The lack of a detailed permanent analysis of processes for providing various social services hinders their effective control and management of risk situations. Undoubtedly this is a complex process and sizing it only by quantitative indicators, which most often uses the National agency for social assistance and the Ministry of Labour and Social Policy, appears as an insufficient information resource for making the right decisions in this direction. The statistics provide a good basis for primary analysis, but not for the consideration of these processes in depth.

\section{REFERENCE LIST}

Terziev, V., Georgiev, M. (2018a). A strategic framework for the development of social entrepreneurship in Bulgaria. // Knowledge - International Journal, August 2018, Institute of Knowledge Management, Skopje, Macedonia, 25, 2018, N1, pp. 23-34, ISSN 1857-923X (for e-version), ISSN 2545 - 4439 (for printed version).

Terziev, V., Georgiev, M. (2018b). Support for the development of social entrepreneurship in Bulgaria. // Knowledge - International Journal, September 2018, Institute of Knowledge Management, Skopje, Macedonia, 26, 2018, N1, pp.57-74, ISSN 1857-923X (for e-version), ISSN 2545 - 4439 (for printed version).

Terziev, V., Georgiev, M. (2018c). Characteristics of the Social Assistance System. // Sbornik dokladi ot godishna universitetska nauchna konferentsiya 14-15 yuni 2018 g., Elektronno izdanie, NVU Vasil Levski- Veliko Tarnovo, Veliko Tarnovo, 2018, str. 959-969, ISBN 978-619-7246-20-9 (online e-book), ISSN 2367-7481 (Терзиев, В., Георгиев, М. Характеристики на системата за социално подпомагане. // Сборник доклади от годишна университетска научна конференция 14-15 юни 2018 г., Електронно издание, НВУ Васил Левски- Велико Търново, Велико Търново, 2018, стр. 959-969, ISBN 978-619-7246-20-9 (online e-book), ISSN 2367-7481).

Terziev, V., Georgiev, M. (2018d). Social Protection of Vulnerable Populations in Bulgaria. // Sbornik dokladi ot godishna universitetska nauchna konferentsiya 14-15 yuni 2018 g., Elektronno izdanie, NVU Vasil 
Levski- Veliko Tarnovo, Veliko Tarnovo, 2018, str. 970-975, ISBN 978-619-7246-20-9 (online e-book), ISSN 2367-7481 (Терзиев, В., Георгиев, М. Социална защита на уязвимите групи от населението в България. // Сборник доклади от годишна университетска научна конференция 14-15 юни 2018 г., Електронно издание, НВУ Васил Левски- Велико Търново, Велико Търново, 2018, стр. 970-975, ISBN 978-619-7246-20-9 (online e-book), ISSN 2367-7481).

Terziev, V., Banabakova, V., Georgiev, M. (2018e). Modern dimensions of social policies. // International journal scientific papers Vol 23.4 Promoted in Budva, Montenegro 24-27.05.2018, IKM - Skopje, 23, 2018, N 4, pp. 935-944, ISSN 1857-923X (for e-version) ISSN 2545- 4439 (for printed version).

Terziev, V., Banabakova, V., Georgiev, M. (2018f). Social support as part of social policy. // International journal scientific papers Vol 23.4 Promoted in Budva, Montenegro 24-27.05.2018, IKM - Skopje, 23, 2018, N 4, pp. 973-980, ISSN 1857-923X (for e-version) ISSN 2545 - 4439 (for printed version).

Terziev, V., Banabakova, V., Georgiev, M. (2018g). Structure of the social welfare system in Bulgaria. // International journal scientific papers Vol 23.4 Promoted in Budva, Montenegro 24-27.05.2018, IKM Skopje, 23, 2018, N 4, pp. 1275-1281, ISSN 1857-923X (for e-version) ISSN 2545 - 4439 (for printed version).

Terziev, V., Banabakova, V., Georgiev, M. (2018h). Role and place of social programing in public governance. // Mizhnarodnoï naukovo-praktichnoï konferentsiï «Zabezpechennya stalogo rozvitku ekonomiki: problemi, mozhlivosti, perspektivi» (16-17 lyutogo 2018 roku, m. Uzhgorod), Ministerstvo osviti i nauki Ukraïni Uzhgorodsykiy natsionalyniy universitet, 2018, s.93-98, ISBN 978-966-916-488-9 (Terziev, V., Banabakova, V., Georgiev, M. Role and place of social programing in public governance. // Міжнародної науково-практичної конференції «Забезпечення сталого розвитку економіки: проблеми, можливості, перспективи» (16-17 лютого 2018 року, м. Ужгород), Міністерство освіти і науки України Ужгородський національний університет, 2018, с.93-98, ISBN 978-966-916-488-9).

Terziev, V., Banabakova, V., Georgiev, M. (2018i). Social program as a product of social programming. // Mizhnarodnoï naukovo-praktichnoï konferentsiï «Zabezpechennya stalogo rozvitku ekonomiki: problemi, mozhlivosti, perspektivi» (16-17 lyutogo 2018 roku, m. Uzhgorod), Ministerstvo osviti i nauki Ukraïni Uzhgorodsykiy natsionalyniy universitet, 2018, s. 99-104, ISBN 978-966-916-488-9 (Terziev, V., Banabakova, V., Georgiev, M. Social program as a product of social programming. // Міжнародної науково-практичної конференції «Забезпечення сталого розвитку економіки: проблеми, можливості, перспективи» (16-17 лютого 2018 року, м. Ужгород), Міністерство освіти і науки України Ужгородський національний університет, 2018, с. 99-104, ISBN 978-966-916-488-9).

Terziev, V., Banabakova, V., Georgiev, M. (2018j). Social efficiency as a measure of social activities. // Mizhnarodnoï naukovo-praktichnoï konferentsiï «Zabezpechennya stalogo rozvitku ekonomiki: problemi, mozhlivosti, perspektivi» (16-17 lyutogo 2018 roku, m. Uzhgorod), Ministerstvo osviti i nauki Ukraïni Uzhgorodsykiy natsionalyniy universitet, 2018, s. 104-109, ISBN 978-966-916-488-9 (Terziev, V., Banabakova, V., Georgiev, M. Assessment of the effectiveness of social programing. // Міжнародної науково-практичної конфреренції «Забезпечення сталого розвитку економіки: проблеми, можливості, перспективи» (16-17 лютого 2018 року, м. Ужгород), Міністерство освіти і науки України Ужгородський національний університет, 2018, с. 110-115, ISBN 978-966-916-4889).

Terziev, V., Banabakova, V., Georgiev, M. (2018k). Social activity of human resource as a basis of effective social policy. // Mizhnarodnoï naukovo-praktichnoï konferentsiï «Zabezpechennya stalogo rozvitku ekonomiki: problemi, mozhlivosti, perspektivi» (16-17 lyutogo 2018 roku, m. Uzhgorod), Ministerstvo osviti i nauki Ukraïni Uzhgorodsykiy natsionalyniy universitet, 2018, s. 116-121, ISBN 978-966-916488-9 (Terziev, V., Banabakova, V., Georgiev, M. Social activity of human resource as a basis of effective social policy. // Міжнародної науково-практичної конфреренції «Забезпечення сталого розвитку економіки: проблеми, можливості, перспективи» (16-17 лютого 2018 року, м. Ужгород), Міністерство освіти і науки України Ужгородський національний університет, 2018, с. 116-121, ISBN 978-966-916-488-9).

Terziev, V., Banabakova, V., Georgiev, M. (2018I). Strategic advantages of an active social program. // Міжнародної науково-практичної конфреренції «Забезпечення сталого розвитку економіки: проблеми, можливості, перспективи» (16-17 лютого 2018 року, м. Ужгород), Міністерство освіти і науки України Ужгородський національний університет, 2018, с. 122-127, ISBN 978-966-916-4889 (Terziev, V., Banabakova, V., Georgiev, M. Strategic advantages of an active social program. // Міжнародної науково-практичної конференції «Забезпечення сталого розвитку економіки: проблеми, можливості, перспективи» (16-17 лютого 2018 року, м. Ужгород), Міністерство освіти і 
IJASOS- International E-Journal of Advances in Social Sciences, Vol. V, Issue 13, April 2019

науки України Ужгородський національний університет, 2018, с. 122-127, ISBN 978-966-916-4889).

Terziev, V., Banabakova, V., Georgiev, M. (2018m). Assessment of the effectiveness of social programming. // Mizhnarodnoï naukovo-praktichnoï konferentsiï «Zabezpechennya stalogo rozvitku ekonomiki: problemi, mozhlivosti, perspektivi» (16-17 lyutogo 2018 roku, m. Uzhgorod), Ministerstvo osviti i nauki Ukraïni Uzhgorodsykiy natsionalyniy universitet, 2018, s. 127-131, ISBN 978-966-916-488-9 (Terziev, V., Banabakova, V., Georgiev, M. Assessment of the effectiveness of social programming. // Міжнародної науково-практичної конференції «Забезпечення сталого розвитку економіки: проблеми, можливості, перспективи» (16-17 лютого 2018 року, м. Ужгород), Міністерство освіти і науки України Ужгородський національний університет, 2018, с. 127-131, ISBN 978-966-916-4889).

Terziev, V., Banabakova, V., Georgiev, M. (2018n). The social program as a part of development strategies. // Mizhnarodnoï naukovo-praktichnoï konferentsiï «Zabezpechennya stalogo rozvitku ekonomiki: problemi, mozhlivosti, perspektivi» (16-17 lyutogo 2018 roku, m. Uzhgorod), Ministerstvo osviti i nauki Ukraïni Uzhgorodsykiy natsionalyniy universitet, 2018, s. 132-137, ISBN 978-966-916-488-9 (Terziev, V., Banabakova, V., Georgiev, M. The social program as a part of development strategies. // Міжнародної науково-практичної конференції «Забезпечення сталого розвитку економіки: проблеми, можливості, перспективи» (16-17 лютого 2018 року, м. Ужгород), Міністерство освіти і науки України Ужгородський національний університет, 2018, с. 132-137, ISBN 978-966-916-4889).

Terziev, V., Banabakova, V., Georgiev, M. (20180). Social programming as a possibility to increase social efficiency. // Mizhnarodnoï naukovo-praktichnoï konferentsiï «Zabezpechennya stalogo rozvitku ekonomiki: problemi, mozhlivosti, perspektivi» (16-17 lyutogo 2018 roku, m. Uzhgorod), Ministerstvo osviti i nauki Ukraïni Uzhgorodsykiy natsionalyniy universitet, 2018, s. 137-142, ISBN 978-966-916488-9 (Terziev, V., Banabakova, V., Georgiev, M. Social programming as a possibility to increase social efficiency. // Міжнародної науково-практичної конференції «Забезпечення сталого розвитку економіки: проблеми, можливості, перспективи» (16-17 лютого 2018 року, м. Ужгород), Міністерство освіти і науки України Ужгородський національний університет, 2018, с. 137-142, ISBN 978-966-916-488-9).

Dimitrova, P., Georgiev, M. (2017a). Model of methodology for determining the needs of continuing vocationaltraining work specialists providing social services. // Innovatsii, tehnologii, nauka. Sbornik statey Mezhdunarodnoy nauchno - prakticheskoy konferentsii 25 yanvarya 2017 g., NITS Aeterna Permy, Chasty 4, 2017, s. 204-235, ISBN 978-5-906925-99-2, ISBN 978-5-00109-000-7 (Dimitrova, P., Georgiev M. Model of methodology for determining the needs of continuing vocationaltraining work specialists providing social services. // Инновации, технологии, наука. Сборник статей Международной научно - практической конференции 25 января 2017 г., НИЦ Аэтерна Пермь, Часть 4, 2017, с. 204-235, ISBN 978-5-906925-99-2, ISBN 978-5-00109-000-7).

Dimitrova, P., Georgiev, M. (2017b). Research, identification and monitoring of the needs of occupational training of social activities experts. // Innovatsii, tehnologii, nauka. Sbornik statey Mezhdunarodnoy nauchno - prakticheskoy konferentsii 25 yanvarya 2017 g., NITS Aeterna Permy, Chasty 4, 2017, s. 235-258, ISBN 978-5-906925-99-2, ISBN 978-5-00109-000-7 (Dimitrova, P., Georgiev M. Research, identification and monitoring of the needs of occupational training of social activities experts. // Инновации, технологии, наука. Сборник статей Международной научно - практической конференции 25 января 2017 г., НИЦ Аэтерна Пермь, Часть 4, 2017, с. 235-258, ISBN 978-5906925-99-2, ISBN 978-5-00109-000-7).

Terziev, V., Banabakova, V., Arabska, E. (2018p). The experience of the centres for provision of integrated employment and social assistance services in Bulgaria. // Upravlenie i Obrazovanie, Universitet "Prof. d-r Asen Zlatarov", Burgas, 14, 2018, N 1, str.5-14, ISSN 13126121. (Terziev, V., Banabakova, V., Arabska, E. The experience of the centres for provision of integrated employment and social assistance services in Bulgaria. // Управление и Образование, Университет “Проф. д-р Асен Златаров", Бургас, 14, 2018, N 1, стр.5-14, ISSN 13126121).

Terziev, V., Arabska, E., Banabakova, V., Kovalyov, E. (2018q). Bolgarsko-Rossiyskoe sotrudnichestvo v oblasti proektirovaniya i realizatsii mezhdunarodnayh setevayh obrazovatelynayh programm. // Sozdanie komfortnoy sreday sotsializatsii uchashtihsya, studentov i uchyonayh, Akademiya za inovatsii i ustoychivost - Plovdiv, Balgariya, 2018, str. 65-69, ISBN 978-619-7246-17-9 (print) ISBN 978-619-7246-18-6 (DVD). Терзиев, В., Арабска, Е., Банабакова, В. Ковалёв, Э. Болгарско- 
Российское сотрудничество в области проектирования и реализации международных сетевых образовательных программ. // Создание комфортной среды социализации учащихся, студентов и учёных, Академия за иновации и устойчивост - Пловдив, България, 2018, стр. 65-69, ISBN 978-619-7246-17-9 (print) ISBN 978-619-7246-18-6 (DVD).

Terziev, V., Arabska, E., Banabakova, V., Ignatova, M., Kovalyov, E. (2018r). Vliyanie tvorchestva G. V. Sviridova na kachestvo sotsializatsii studencheskoy molodyozhi. // Sozdanie komfortnoy sreday sotsializatsii uchashtihsya, studentov i uchyonayh, Akademiya za inovatsii i ustoychivost - Plovdiv, Balgariya, 2018, str. 71-80, ISBN 978-619-7246-17-9 (print) ISBN 978-619-7246-18-6 (DVD). Терзиев, В., Арабска, Е., Банабакова, В., Игнатова, М., Ковалёв, Э. Влияние творчества Г. В. Свиридова на качество социализации студенческой молодёжи. // Создание комфортной среды социализации учащихся, студентов и учёных, Академия за иновации и устойчивост - Пловдив, България, 2018, стр. 71-80, ISBN 978-619-7246-17-9 (print) ISBN 978-619-7246-18-6 (DVD).

Terziev, V., Arabska, E., Banabakova, V. (2018s). Sotsialyno-ekonomicheskoe polozhenie nezashtishtyonnayh sloyov naseleniya. // Sozdanie komfortnoy sreday sotsializatsii uchashtihsya, studentov i uchyonayh, Akademiya za inovatsii i ustoychivost - Plovdiv, Balgariya, 2018, str. 87-89, ISBN 978-619-7246-17-9 (print) ISBN 978-619-7246-18-6 (DVD). Терзиев, В., Арабска, E., Банабакова, В. Социально-экономическое положение незащищённых слоёв населения. // Создание комфортной среды социализации учащихся, студентов и учёных, Академия за иновации и устойчивост - Пловдив, България, 2018, стр. 87-89, ISBN 978-619-7246-17-9 (print) ISBN 978-619-7246-18-6 (DVD).

Terziev, Venelin. (2016a). Process of deinstitutionalization of children at risk in Bulgaria. // Fifth Annual International Research-to-Practice Conference «Early Childhood Care and Education» (ECCE 2016). 12-14 May, 2016, Lomonosov Moscow State University - MSU, Moscow, Russia, 2016, ISSN 23086408, pp.170-179.

Terziev, Venelin. (2017c). Prevention and support to persons at risk of social marginalization. // Children \& Schools, 39, 2017, N 4(2), pp. 1139- 1150, ISSN 1532-8759, Source Normalized Impact per Paper (SNIP): 0.400 SCImago Journal Rank (SJR): 0.211 Impact factor: 1.086 5-Yr impact factor: 1.152.

Terziev, V., Radev, D., Arabska, E., Dimitrovski, R. (2017d). Deinstitutionalisation of children as part of the development of social services in Bulgaria. // Twelfth international scientific conference Knowledge without borders, 31.3-2.4.2017, Vrnjacka Banja, Serbia, Institute of Knowledge Management, Skopje 16, 2017, N 1, ISSN 1857-923X, pp.19-28.

Terziev, Venelin. (2017e). The system of social services in Bulgaria and the process of deinstitutionalisation of children. // Proceedings of the VII International Academic Congress "Fundamental and Applied Studies in EU and CIS Countries" (United Kingdom, Cambridge, England, 26-28 February 2017). Cambridge University Press, 7, 2017, ISBN: 978-0-875-83597-4, pp.338-351, Source Normalized Impact per Paper (SNIP): 5.192 SCImago Journal Rank (SJR): 5.186 Impact factor: 7.549. 